\title{
PENGARUH STRATEGI PEMBELAJARAN KOOPERATIF DAN KEMAMPUAN VERBAL TERHADAP HASIL BELAJAR ILMU PENGETAHUAN SOSIAL
}

\author{
Burhanuddin $^{1}$ dan Harun Sitompul ${ }^{2}$ \\ MTs Ululmul Qur'an Langsa ${ }^{1}$ dan Universitas Negeri Medan ${ }^{2}$ \\ burhanuddin@gmail.com ${ }^{l}$ dan prof_runsit@yahoo.co.id ${ }^{2}$
}

\begin{abstract}
Abstrak: Tujuan penelitian ini adalah untuk mengetahui: (1) hasil belajar IPS siswa yang diajar dengan menggunakan strategi pembelajaran TGT lebih tinggi daripada hasil belajar siswa yang diajar dengan menggunakan strategi pembelajaran pendekatan struktural, (2) hasil belajar IPS antara siswa dengan karakteristik kemampuan verbal tinggi lebih tinggi daripada hasil belajar siswa dengan karakteristik kemampuan verbal rendah, dan (3) interaksi antara strategi pembelajaran dan kemampuan verbal terhadap hasil belajar IPS. Teknik analisis adalah Anava dua jalur pada taraf signifikansi $\alpha=0,05$ yang dilanjutkan dengan uji Scheffe. Hasil penelitian adalah: (1) rata-rata hasil belajar IPS siswa yang diajar dengan strategi pembelajaran kooperatif TGT lebih tinggi daripada diajar dengan strategi pembelajaran kooperatif pendekatan struktural dengan $F_{\text {hitung }}=11,78>F_{\text {tabel }}=4,018$, (2) rata-rata hasil belajar IPS siswa dengan kemampuan verbal tinggi lebih tinggi daripada kemampuan verbal rendah, dengan $F_{\text {hitung }}=26,82>F_{\text {tabel }}=$ 4,018, dan (3) terdapat interaksi antara strategi pembelajaran dan kemampuan verbal terhadap hasil belajar IPS dengan $F_{\text {hitung }}=17,29>F_{\text {tabel }}=4,018$.
\end{abstract}

Kata Kunci: strategi pembelajaran kooperatif, kemampuan verbal, ilmu pengetahuan sosial

Abstract: The aim of this study was to determine: (1) the results of social studies students are taught using learning strategies TGT higher than the learning outcomes of students taught using learning strategy structural approach, (2) the results of social studies among students with the characteristics of verbal ability height higher than the characteristics of student learning outcomes with low verbal abilities, and (3) the interaction between learning strategy and verbal skills to the learning outcomes IPS. Anova analysis technique is two lanes at significance level $\alpha=0.05$, followed by Scheffe test. Results of the study are: (1) an average of the results of social studies students taught by cooperative learning strategies TGT higher than taught by cooperative learning strategies with the structural approach of $F=11.78>F$ table $=4.018,(2)$ the average results of learning IPS students with higher verbal skills are higher than low verbal ability, with Fhitung $=$ 26.82> F table $=4.018$, and (3) there is interaction between learning strategies and verbal skills to the learning outcomes with the IPS of $F=17.29>F$ table $=4.018$.

Keywords: cooperative learning strategies, verbal skills, social

\section{PENDAHULUAN}

Dalam rangka mengatasi persoalan perolehan hasil belajar siswa yang masih relatif rendah, berbagai upaya dilakukan untuk meningkatkan kemampuan pemahaman siswa khususnya pada bidang studi IPS. Baik dari teori maupun hasil-hasil penelitian menunjukkan bahwa faktor utama yang berpengaruh langsung terhadap hasil belajar adalah proses pembelajaran. Oleh karena itu upaya meningkatkan kualitas pembelajaran dan penerapan strategi pembelajaran yang lebih tepat mempunyai peran penting. Strategi pembelajaran yang dikembangkan haruslah berpusat dan menitikberatkan pada keaktifan siswa. Melalui pemilihan strategi pembelajaran yang tepat, harapan-harapan peningkatan mutu dan hasil belajar dapat dipenuhi. Untuk itu dituntut kemampuan guru menguasai teknologi pembelajaran untuk merencanakan, merancang, melaksanakan dan mengevaluasi serta melakukan feedback menjadi faktor penting guna mencapai keberhasilan tujuan pembelajaran. Kemampuan guru menguasai materi pembelajaran, gaya mengajar, penggunaan media, penentuan strategi dan pemilihan strategi pembelajaran merupakan usaha-usaha untuk melancarkan proses 
pembelajaran dan meningkatkan hasil pencapaian tujuan pembelajaran.

Slameto (2005) menyatakan agar siswa dapat belajar dengan baik maka strategi pembelajaran harus dilakukan secara tepat dan efektif. Tepat dimaknai bahwa strategi pembelajaran hendaknya disesuaikan dengan karakteristik materi ajar sedangkan efektif dimaknai bahwa strategi pembelajaran yang diterapkan dapat meningkatkan hasil belajar. Selanjutnya Slameto (2005) menjelaskan strategi pembelajaran yang digunakan guruguru selama ini belum optimal sehingga menyebabkan timbulnya kebosanan siswa yang berakibat rendahnya hasil belajar.

Untuk mengurangi atau bahkan menghindari strategi pembelajaran yang terlalu monoton diupayakan berbagai strategi pembelajaran yang lebih efektif dalam menciptakan komunikasi yang multi arah, sehingga diharapkan juga menimbulkan dan meningkatkan interaksi yang proaktif dalam pembelajaran. Namun perlu disadari bahwa strategi pembelajaran tersebut tidak ada yang terbaik atau buruk, karena strategi pembelajaran tersebut memiliki kelebihan dan kekurangan. Seperti yang diungkapkan Sudjana (1998) bahwa setiap metode mengajar ada keunggulan dan kelemahan. Untuk itu pemilihan strategi pembelajaran yang tepat dibutuhkan dan harus disesuaikan dengan karakteristik materi ajar dan karakteristik siswa, karena mempelajari materi IPS yang cukup padat dituntut kemampuan siswa dalam mencari sumbersumber lain.

Hamalik (2003) menjelaskan belajar adalah modifikasi atau memperteguh kelakuan melalui pengalaman. Mulyati (2005) menjelaskan bahwa belajar adalah merupakan suatu usaha sadar individu untuk mencapai tujuan peningkatan diri atau perubahan diri melalui latihan-latihan dan pengulanganpengulangan dan perubahan yang terjadi bukan karena peristiwa kebetulan.

Hergenhahn dan Olson (2008:8) menjelaskan bahwa belajar adalah perubahan prilaku atau potensi prilaku yang relatif permanen dan berasal dari pengalaman dan tidak bisa dinisbahkan ke temporary body state (keadaan tubuh temporer) seperti keadaan yang disebabkan oleh sakit, keletihan atau obatobatan. Selanjutnya Hergenhahn dan Olson (2008) menjelaskan lima hal yang harus diperhatikan berkaitan dengan belajar yaitu: (1) belajar diukur berdasarkan perubahan dalam prilaku, (2) perubahan prilaku (behavioral) ini relatif permanen, (3) perubahan prilaku itu tidak selalu terjadi secara langsung setelah proses belajar selesai, (4) perubahan prilaku berasal dari pengalaman atau latihan, dan pengalaman atau latihan harus diperkuat

Woolfolk (2009) menjelaskan belajar adalah suatu proses perubahan permanen pada pengetahuan atau prilaku yang diakibatkan oleh pengalaman. Selanjutnya dijelaskan Woolfolk bahwa untuk syarat yang harus dipenuhi dalam definisi belajar tersebut yaitu: (1) perubahan itu harus diwujudkan oleh pengalaman yaitu interaksi individu dengan lingkungannya, (2) perubahan itu tidak sebabkan oleh kematangan seperti tubuh menjadi lebih tinggi atau rambut yang mulai berubah, dan (3) perubahan akibat sakit, kelelahan atau kelaparan bukan termasuk definisi belajar tersebut.

Suryabrata (2002) menjelaskan belajar merupakan suatu proses perubahan tingkah laku sebagai suatu hasil interaksi dengan lingkungannya dalam memenuhi kebutuhannya dengan ciri-ciri: (1) perubahan terjadi secara sadar, (2) perubahan dalam belajar terjadi bersifat kontinu dan fungsional, (3) perubahan dalam belajar

terjadi bersifat positif dan aktif artinya perubahan itu senantiasa bertambah dan tertuju untuk memperoleh sesuatu yang lebih baik dari sebelumnya, (4) perubahan dalam belajar bukan bersifat sementara, tetapi bersifat permanen, (5) perubahan dalam belajar bertujuan terarah, dan (6) perubahan dalam belajar mencakup seluruh aspek tingkah laku. Selanjutnya Suryabrata (2002) menjelaskan bahwa di dalam belajar terdapat beberapa hal yang pokok untuk dipahami yaitu: (1) belajar membawa perubahan dalam arti behavioural change (perubahan tingkah laku), aktual maupun potensial, (2) perubahan tersebut pada pokoknya adalah didapatkannya kecakapan baru, (3) perubahan itu terjadi karena usahausaha atau dengan sengaja.

Hitzman (dalam Syah, 2004) menjelaskan belajar adalah suatu perubahan yang terjadi dalam diri organisme, manusia atau hewan, disebabkan oleh pengalaman yang dapat mempengaruhi tingkah laku organisme tersebut. Dari beberapa pendapat ahli mengenai belajar maka dapatlah dimaknai bahwa belajar adalah usaha untuk memperoleh pengetahuan dan keterampilan yang ditandai dengan adanya perubahan tingkah laku individu dari tidak tahu menjadi tahu dan tidak dapat memiliki keterampilan menjadi memiliki keterampilan. 
Romizowski (1981) menyatakan bahwa hasil belajar diperoleh dalam bentuk yaitu: (1) pengetahuan, dan (2) keterampilan. Selanjutnya Romizowski (1981) menjelaskan pengetahuan dikelompokkan kepada empat kategori, yaitu fakta, konsep, prinsip dan prosedur. Fakta merupakan pengetahuan tentang obyek nyata yang merupakan asosiasi dari kenyataankenyataan dan informasi verbal dari suatu obyek, peristiwa atau manusia. Konsep merupakan pengetahuan tentang seperangkat obyek konkrit atau definisi. Prinsip adalah merupakan pernyataan mengenai hubungan dua konsep atau lebih, hubungan itu bisa bersifat kausalitas, korelasi atau aksiomatis. Prosedur merupakan pengetahuan tentang tindakan demi tindakan yang bersifat linier dalam mencapai suatu tujuan .

Gagne (1977) menjelaskan lima tipe hasil belajar yaitu: (1), intelektual skill, (2) cognitive strategy (3) verbal information, (4) attitude, dan (5) motor skill. Sedangkan Howard Kingsley dalam Sudjana (2002) menjelaskan tiga macam hasil belajar yakni: keterampilan dan kebiasaan, (2) pengetahuan dan pengertian dan (3) sikap dan cita-cita dapat diisi dengan bahan yang ditetapkan dalam kurikulum sekolah.

$$
\text { Merril dan Twitchell }
$$

mengelompokkan hasil belajar ke dalam dua dimensi yaitu tingkat kinerja (performance) dan tipe isi (content matrix). Dimensi tingkat kinerja terdiri dari mengingat, menggunakan, dan menemukan. Mengingat berkaitan dengan kinerja yang menuntut siswa melakukan penelusuran struktur ingatan agar dapat mengungkapkan kembali konstruk-konstruk yang telah disimpan di dalamnya. Menggunakan berkaitan dengan kinerja yang menuntut siswa menerapkan suatu abstraksi pada kasus-kasus khusus. Menemukan berkaitan dengan unjuk kerja yang menuntut siswa menemukan atau mengembangkan abstraksi baru.

Bloom dkk (dalam Arikunto, 2002) menjelaskan domain psikomotor terdiri: (1) Meniru. Tujuan pembelajaran pada tingkat ini diharapkan peserta didik dapat meniru suatu perilaku yang dilihatnya, (2) Manipulasi. Tujuan pembelajaran pada tingkat ini menuntut peserta didik untuk melakukan suatu perilaku tanpa bantuan visual, sebagaimana pada tingkat meniru. Tetapi diberi petunjuk berupa tulisan atau instruksi verbal, (3) Ketepatan Gerakan. Tujuan pembelajaran pada level ini peserta didik mampu melakukan suatu perilaku tanpa menggunakan contoh visual maupun petunjuk tertulis, dan melakukannya dengan lancar, tepat, seimbang dan akurat, (4) Artikulasi. Tujuan pembelajaran pada level ini peserta didik mampu menunjukkan serangkaian gerakan dengan akurat, urutan yang benar, dan kecepatan yang tepat, dan (5) Naturalisasi. Tujuan pembelajaran pada tingkat ini peserta didik mampu melakukan gerakan tertentu secara spontan tanpa berpikir lagi cara melakukannya dan urutannya.

Berkaitan dengan bidang studi IPS untuk tingkat sekolah menengah pertama Departemen Pendidikan Nasional (2006) menjelaskan bahwa mata pelajaran IPS untuk tingkat sekolah menengah pertama bertujuan agar peserta didik memiliki kemampuan: (1) mengenal konsep-konsep yang berkaitan dengan kehidupan masyarakat dan lingkungannya, (2) memiliki kemampuan dasar untuk berpikir logis dan kritis, rasa ingin tahu, inkuiri, memecahkan masalah, dan keterampilan dalam kehidupan sosial, (3) memiliki komitmen dan kesadaran terhadap nilai-nilai sosial dan kemanusiaan, dan (4) memiliki kemampuan berkomunikasi, bekerjasama dan berkompetisi dalam masyarakat yang majemuk, di tingkat lokal, nasional, dan global.

Selanjutnya Departemen Pendidikan Nasional (2006) menjelaskan ruang lingkup mata pelajaran IPS untuk tingkat sekolah menengah pertama meliputi aspek-aspek: (1) manusia, tempat, dan lingkungan, (2) waktu, keberlanjutan, dan perubahan, (3) sistem sosial dan budaya, dan (4) perilaku ekonomi dan kesejahteraan.

Dick, Carey dan Carey (2005) menjelaskan strategi pembelajaran adalah prosedur atau tahapan kegiatan belajar yang digunakan dalam rangka membantu peserta didik mencapai tujuan pembelajaran tertentu. Prosedur atau tahapan kegiatan belajar itu mungkin dilakukan pengajar mungkin juga dilakukan oleh siswa sendiri dengan menggunakan buku, gambar, program televisi atau kombinasi berbagai media, baik oleh pengajar maupun oleh siswa sendiri, kegiatan itu haruslah terencana secara sistematik untuk dapat disebut kegiatan pembelajaran. Selanjutnya dijelaskan Dick, Carey dan Carey (2005) mengatakan bahwa strategi pembelajaran memuat lima komponen utama yaitu: (1) aktivitas pembelajaran pendahuluan, (2) penyampaian informasi, (3) partisipasi siswa, (4) tes, (5) kegiatan lanjutan. 
Suparman (2001) mendefinisikan strategi pembelajaran sebagai perpaduan dari (1) urutan kegiatan instruksional, (2) cara pengorganisasian materi pengajaran dan siswa, (3) peralatan dan bahan dan (4) waktu yang digunakan dalam proses pembelajaran. Kedua definisi yang dikemukakan para ahli di atas pada prinsipnya lebih menekankan pada aspek komponen dan prosedur pengajaran.

Romizowski (1981) berpendapat bahwa strategi pembelajaran merupakan suatu pendekatan menyeluruh yang dapat dibedakan menjadi dua strategi dasar, yaitu ekspositori dan inquiri. Kedua strategi ini dapat dipandang sebagai dua ujung yang sejalan dalam suatu kontinum strategi, hal ini erat sekali kaitannya dengan pendekatan deduktif dimana strategi ini dimulai dengan penyajian informasi mengenai prinsip atau kaidah kemudian diikuti dengan tes penguasaan, penerapan dalam bentuk contoh dan penerapan pada situasi tertentu. Sedangkan strategi inquiri/diskoveri didasarkan pada teori belajar pengalaman yang disebut juga teori belajar pengalaman.

Merill (1981) mengklasifikasikan strategi pembelajaran atas tiga dasar (1) tujuan pengajaran meliputi sepuluh kombinasi antara jenis materi dan tingkah laku yang diharapkan, (2) cara mempresentasikan materi yaitu dari tingkat yang khusus ke tingkat yang umum atau sebaliknya dari tingkat yang umum ke tingkat khusus, (3) bentuk respon siswa dibedakan atas strategi ekspositori dan inkuri. Romizowski (1981) menyatakan bahwa setiap strategi pembelajaran yang dikembangkan selalu mencerminkan posisi teoretis yang dianut tentang bagaimana seharusnya pembelajaran itu dilaksanakan. Oleh karena itu guru sebagai penyelenggara kegiatan pembelajaran dituntut mampu mengupayakan terjadinya interaksi siswa dengan komponen sistem pembelajaran yang lain secara optimal. Mudhoffir (1993) memberikan pengertian strategi pembelajaran sedikit lebih luas karena di dalamnya termasuk juga pengertian pendekatan pengajaran dalam penyampaian informasi, memilih sumber penunjang pengajaran dan menentukan serta menjelaskan peranan siswa dalam menyusun program pembelajaran yang memperhatikan kondisi lingkungan siswa agar proses pelajaran menjadi lebih efektif.

Berkaitan dengan penerapan strategi pembelajaran dalam kegiatan pembelajaran Sanjaya (2007) menjelaskan yaitu: (1) pertimbangan yang berhubungan dengan tujuan yang ingin dicapai, apakah tujuan pembelajaran yang ingin dicapai berkenaan aspek kognitif, afektif dan psikomotorik, bagaimana kompleksitas tujuan pembelajaran yang ingin dicapai dan apakah untuk mencapai tujuan memerlukan keterampilan akademis, (2) pertimbangan yang berhubungan dengan bahan atau materi pembelajaran, apakah materi pelajaran berupa fakta, konsep, hukum atau teori tertentu, apakah untuk mempelajari materi pelajaran memerlukan prasyarat tertentu atau tidak, dan apakah tersedia buku-buku sumber untuk mempelajari materi tersebut, (3) pertimbangan dari sudut siswa, apakah strategi pembelajaran sesuai dengan tingkat kematangan siswa, apakah strategi pembelajaran itu sesuai dengan minat, bakat, dan kondisi siswa, dan apakah strategi pembelajaran itu sesuai dengan gaya belajar siswa, dan (4) pertimbanganpertimbangan lainnya, apakah untuk mencapai tujuan hanya cukup dengan satu strategi saja, apakah strategi yang ditetapkan dianggap satusatunya strategi yang dapat digunakan, dan apakah strategi itu memiliki efektivitas dan efisiensi?.

Suparno (1997) menjelaskan bahwa prinsip-prinsip konstruktivisme adalah: (1) pengetahuan dibangun oleh siswa sendiri, baik secara personal maupun sosial, (2) pengetahuan tidak dapat dipindahkan dari pengajar ke siswa kecuali dengan keaktifan siswa sendiri untuk menalar, (3) siswa aktif mengkonstruksi terus menerus sehigga terjadi perubahan konsep menuju ke konsep yang lebih rinci, lengkap serta sesuai dengan konsep ilmiah dan (4) pengajar sekedar membantu menyediakan sarana dan situasi agar proses konstruksi siswa berjalan mulus.

Selanjutnya Slavin (2009) menjelaskan bahwa pembelajaran konstruktivisme menekankan masing-masing siswa menemukan dan mengubah informasi yang rumit dengan memeriksa informasi baru terhadap aturan lama dan mengubah aturan apabila hal itu tidak lagi berguna. Muijs dan Reynolds (2008) menjelaskan bahwa pembelajaran konstruktivisme yaitu siswa mengkonstruksikan pengetahuan secara aktif dan tidak menerima begitu saja dari guru. Belajar adalah sebuah pencarian makna, di mana guru berperan mendorong siswa untuk mengkonstruksikan makna dengan menstrukturisasikan berbagai kegiatan di seputar ide-ide besar dan eksplorasi, memberi siswa cukup waktu untuk mengeksplorasi berbagai konsep secara seksama dan menghubungkan pengetahuan baru 
dengan apa yang sudah diketahui siswa. Selanjutnya Arends (2008) menjelaskan pendekatan pembelajaran konstruktivisme adalah pandangan yang menjadi belajar adalah sebuah kegiatan sosial dan kultural dan pengetahuan bersifat personal oleh karena itu siswa mengkonstruksi makna melalui interaksi dengan orang lain.

Arends

(2008) menjelaskan pembelajaran kooperatif adalah strategi yang unik di antara strategi-strategi pengajaran lainnya karena menggunakan struktur tujuan, tugas dan reward yang berbeda untuk mendukung pembelajaran siswa. Hal senada diungkapkan Lie (2004:29) bahwa pembelajaran kooperatif bukan sekedar belajar secara kelompok, melainkan pada penstrukturan atau sistem kerja/belajar kelompok yang terstruktur.

Lie (2004) menjelaskan unsur-unsur pembelajaran kooperatif yaitu: (1) saling ketergantungan positif. Unsur ini menunjukkan bahwa dalam pembelajaran kooperatif ada dua pertanggungjawaban kelompok: mempelajari bahan yang ditugaskan kepada kelompok, dan (b) menjamin semua anggota kelompok secara individu mempelajari bahan yang ditugaskan tersebut, (2) tanggung jawab perseorangan, merupakan kunci untuk menjamin semua anggota yang diperkuat oleh kegiatan belajar bersama (3) tatap muka, (4) komunikasi antar anggota, dan (5) evaluasi proses kelompok.

Riyanto (2010) menjelaskan karakteristik pembelajaran kooperatif adalah yaitu: (1) kelompok dibentuk dengan siswa kemampuan tinggi, sedang dan rendah, (2) siswa dalam kelompok sehidup semati, (3) siswa melihat semua anggota mempunyai tujuan yang sama, (4) membagi tugas dan tanggung jawab sama, (5) akan dievaluasi untuk semua, (6) berbagi kepemimpinan dan keterampilan untuk bekerjasama dan (7) diminta mempertanggungjawabkan individual materi yang ditangani. Sedangkan Sanjaya (2007) menjelaskan karakteristik pembelajaran kooperatif yaitu: (1) pembelajaran secara tim, (2) didasari pada manajemen kooperatif, (3) kemauan untuk bekerja sama, dan (4) keterampilan bekerja sama.

$$
\text { Sanjaya (2007) menjelaskan }
$$

keunggulan pembelajaran kooperatif yaitu: (1) siswa tidak terlalu menggantungkan pada guru, akan tetapi dapat menambah kepercayaan kemampuan berpikir sendiri, menemukan informasi dari berbagai sumber dan belajar dari siswa lainnya, (2) mengembangkan kemampuan mengungkapkan ide atau gagasan dengan katakata secara verbal dan membandingkannya dengan ide-ide lain, (3) membantu siswa untuk respek dan menyadari akan segala keterbatasannya serta menerima segala perbedaan, (4) membantu memberdayakan setiap siswa untuk lebih bertanggung jawab dalam belajar, (5) strategi pembelajaran mampun meningkatkan prestasi akademik, kemampuan sosial, harga diri, kemampuan interperonal dan keterampilan mengatur waktu dan sikap positif terhadap sekolah, (6) meningkatkan motivasi dan memberi rangsangan untuk berpikir.

Sedangkan keterbatasan pembelajaran kooperatif dijelaskan Sanjaya (2007) yaitu: (1) untuk memahami dan mengerti filosofi pembelajaran kooperatif membutuhkan waktu, (2) ciri utama pembelajaran kooperatif adalah siswa saling membelajarkan oleh karena itu tanpa peer teaching yang efektif, maka dibandingkan dengan pengajaran langsung dari guru, maka materi ajar yang seharusnya dikuasai siswa bisa saja tidak tercapai, (3) penilaian yang diberikan dalam pembelajaran kooperatif didasarkan kepada hasil kerja kelompok, namun demikian, guru menyadari bahwa sebenarnya hasil yang diharapkan adalah hasil setiap individu siswa, (4) keberhasilan pembelajaran kooperatif dalam upaya mengembangkan kesadaran berkelompok memerlukan periode waktu yang cukup panjang, oleh karena itu tidak mungkin tercapai hanya dengan satu kali atau dua kali penerapan pembelajaran kooperatif, dan (5) walaupun kemampuan bekerjasama merupakan kemampuan yang penting untuk siswa, akan tetapi banyak aktivitas dalam kehidupan yang didasarkan kepada kemampuan individual. Oleh karena itu melalui pembelajaran kooperatif selain siswa belajar bekerjasama, siswa juga harus belajar bagaimana membangun kepercayaan diri. Untuk mencapai kedua hal itu dalam pembelajaran pembelajaran kooperatif memang bukanlah hal yang mudah.

Slavin (2009) menjelaskan pembelajaran kooperatif TGT dikembangkan oleh De Vries dan Edwards. Pembelajaran kooperatif TGT adalah suatu tipe pembelajaran kooperatif yang menuntut siswa bekerja sama dalam satu kelompok yang terdiri dari 4-5 orang untuk saling membantu, saling memberi arahan dan bimbingan di dalam memahami materi yang disampaikan oleh guru untuk bekal dalam turnamen. Lebih lanjut Trianto (2009) 
menjelaskan TGT dapat digunakan dalam berbagai macam mata pelajaran dan dari jenjang pendidikan dasar sampai perguruan tinggi.

Pada kegiatan ini sekelompok siswa belajar dengan porsi utamanya mendiskusikan tugas-tugas yang ada di dalam pelajaran IPS, dalam arti saling membantu menyelesaikan tugas dan memecahkan masalah. Pada pembelajaran kooperatif TGT, siswa diberi lembar kegiatan yang berisi pertanyaan atau tugas yang direncanakan untuk diajarkan. Dalam pembelajaran kooperatif TGT, siswa diberi penekanan bahwa mereka belum boleh mengakhiri diskusinya sebelum mereka yakin bahwa seluruh anggota timnya menyelesaikan seluruh tugas dan disaat siswa bekerja, guru mengamati bagaimana kelompok bekerja.

Trianto (2009) menjelaskan bahwa pada pembelajaran TGT, siswa ditempatkan dalam tim belajar beranggota beberapa siswa yang merupakan campuran menurut tingkat prestasi, jenis kelamin dan suku. Guru menyiapkan pelajaran kemudian siswa bekerja dalam tim kemudian diberi kuis berupa soal yang harus dikerjakan siswa. Kemudian guru memastikan siswa bekerja dalam kelompoknya dan memastikan siswa telah menguasai materi ajar.

Selanjutnya Taniredja, Faridli dan Harmianto (2011) menjelaskan aktivitas pembelajaran kooperatif TGT sebagai berikut: (1) langkah-langkah dalam pembelajaran kooperatif TGT mengikuti aturan sebagai berikut: pengaturan klasikal, belajar kelompok, turnamen akademik, penghargaan tim dan pemindahan, (2) pembelajaran diawali dengan memberikan pelajaran, selanjutnya diumumkan kepada semua siswa bahwa akan melaksanakan pembelajaran kooperatif TGT dan siswa diminta memindahkan kursi untuk membentuk meja tim. Kepada siswa disampaikan bahwa mereka akan bekerjasama dengan kelompok belajar selama beberapa pertemuan, mengikuti turnamen akademik untuk memperoleh nilai tim mereka serta diberiyahukan tim yang mendapat nilai tinggi akan mendapat penghargaan, (3) kegiatan dalam turnamen adalah persaingan pada meja turnamen dari 4-5 siswa dari tim yang berbeda dengan kemampuan setara, (4) pada akhir putaran pemenang mendapat satu kartu bernomor, penantang yang kalah mengembalikan perolehan kartunya bila sudah ada namun jika kalah tidak diberikan hukuman. Penskoran didasarkan pada jumlah perolehan kartu misalnnya pada meja turnamen terdiri dari 3 siswa yang tidak seri, peraih nilai tertinggi mendapat skor 60, kedua 40 dan ketiga 20, (5) dengan model yang mengutamakan kerja kelompok dan kemampuan menyatukan intelegensi siswa yang berbeda-beda akan dapat membuat siswa mempunyai nilai dalam segi kognitif, afektif dan psikomotorik secara merata satu siswa dengan sioswa yang lain.

Pembelajaran kooperatif pendekatan struktural dikembangkan oleh Frank Lyman dari Universitas Maryland. Arends (2008) menjelaskan bahwa pendekatan struktural menekankan penggunaan struktur tertentu yang dirancang untuk mempengaruhi pola interaksi peserta didik. Struktur yang dikembangkan dimaksudkan untuk sebagai alternatif untuk struktur kelas yang lebih tradisional seperti resitasi, bahwa tenaga pengajar mengajukan pertanyaan-pertanyaan kepada seluruh kelas dan peserta didik memberikan jawaban setelah mengangkat tangan dan dipanggil namanya.

Pembelajaran kooperatif pendekatan struktural tetap memperhatikan prinsip-prinsip dasar pembelajaran kooperatif, dalam hal ini Stahl (dalam Solihatin dan Raharjo, 2008) yaitu: (1) perumusan tujuan belajar harus jelas, (2) penerimaan yang menyeluruh oleh peserta didik tentang tujuan belajar, (3) ketergantungan yang bersifat positif, (4) interaksi yang bersifat terbuka, (5) tanggung jawab individu, (6) kelompok bersifat heterogen, (7) interaksi sikap dan prilaku sosial yang positif, (8) tindak lanjut, dan (9) kepuasan dalam belajar. Selanjutnya Lie (2004:8) menjelaskan lima unsur yang diperhatikan dalam strategi pembelajaran kooperatif yaitu: (1) saling ketergantungan positif, (2) tanggung jawab perseorangan, (3) tatap muka, (4) komunikasi antar anggota, dan (5) evaluasi proses kelompok.

Pembelajaran kooperatif dengan pendekatan struktural yang dikembangkan Frank Lyman adalah dengan Think-Pair-Share (Arend, 2008). Pendekatan ini mengasumsikan bahwa semua resitasi atau diskusi perlu dilakukan dalam setting seluruh kelompok, dan memiliki prosedur-prosedur built-in untuk memberikan lebih banyak waktu kepada peserta didik untuk berpikir, untuk merespons dan untuk saling membantu. Melalui pembelajaran Think-Pair-Share (TPS) siswa diberikan kesempatan dan waktu lebih banyak berpikir, menjawab dan saling membantu satu sama lain, serta teknik ini memberikan kesempatan kepada siswa untuk bekerja sendiri dan bekerjasama dengan teman-temannya.

Kemampuan verbal adalah kemampuan untuk menyusun pikiran dengan jelas dan 
mampu menggunakan kemampuan ini secara kompeten melalui kata-kata untuk mengungkapkan pikiran-pikiran ini dalam berbicara, membaca dan menulis. Thurstone seperti yang dikutip dalam Azwar (2004) mengatakan bahwa kemampuan verbal yaitu kemampuan untuk memahami hubungan/makna kata, kosakata, dan penguasaan komunikasi lisan. Selanjutnya menurut Lewin, dkk., (2005) bahwa kemampuan verbal adalah kemampuan untuk menyusun pikiran dengan jelas dan mampu menggunakan kemampuan ini secara kompeten melalui kata-kata untuk mengungkapkan pikiran-pikiran ini dalam berbicara, membaca dan menulis.

Individu yang memiliki kemampuan verbal berciri utama adanya kecakapan berbicara dengan jelas, teratur dan lancar serta memiliki perbendaharaan kata-kata yang baik dengan ciri-ciri khusus individu yang memiliki kemampuan verbal yang tinggi yaitu: (1) memiliki kosakata yang baik; (2) membaca dengan penuh pemahaman; (3) ingin tahu secara intelektual; dan (4) menunjukkan keingintahuan.

Untuk mengukur kemampuan verbal ini para ahli merancang tes yaitu Differential Aptitude Test (DAT). Tes ini paling sering digunakan untuk mengukur sekelompok kemampuan dasar seseorang. Menurut Anastasi (1998) faktor yang di tes DAT yaitu: kemampuan verbal, kemampuan mengeja (spelling), dan penggunaan bahasa. Sehubungan dengan kemampuan verbal dalam tes DAT kemampuan verbal dirancang untuk mengukur kemampuan berpikir abstrak, generalisasi, dan konstruktif dengan memahami konsep verbal. Tes kemampuan verbal memakai perbendaharaan kata yang luas, berasal dari berbagai bidang ilmu seperti sejarah, geografi, sastra, seni, dan sebagainya.

Ada juga tes untuk mengukur kemampuan verbal yaitu tes Wechsler Adult Intelligence Scale - Revised (WAIS - R). Menurut Wechles (dalam Aiken, 1997) tes WAIS - R terbagi atas 2 bagian yaitu skala verbal dan skala performance. Sehubungan dengan kemampuan verbal dalam tes WAIS - R yang dites dalam skala verbal yaitu: (1) pengetahuan umum (information); yaitu pertanyaan-pertaanyaan mengenai informasi yang umum; (2) pengertian umum (comprehension); yaitu untuk mengukur informasi praktis dan kemampuan untuk mengevaluasi pengalaman masa lampau; (3) kecepatan berhitung (arithmetic); yaitu soal- soal verbal yang mengukur penalaran masa lampau; (4) persamaan (similarities); yaitu menanyakan kesamaan objek atau konsep tertentu dan mengukur pemikiran abstrak; (5) deret angka (digit span); yaitu serangkaian angka yang disajikan secara auditoris; dan (6) perbendaharaan kata (vocabulary); yaitu mengukur pengetahuan kata.

Masalah penelitian ini dapat dirumuskan adalah: (1) Apakah terdapat pengaruh strategi pembelajaran TGT dengan strategi pembelajaran pendekatan struktural terhadap hasil belajar IPS siswa?; (2) Apakah terdapat pengaruh karakteristik kemampuan verbal tinggi dengan kemampuan verbal rendah terhadap hasil belajar IPS siswa?; dan (3) Apakah terdapat interaksi antara strategi pembelajaran dan kemampuan verbal terhadap hasil belajar IPS?

\section{METODE}

Penelitian ini dilaksanakan di Madrasah Tsanawiyah (MTs) Ulumul Qur'an Langsa. Populasi penelitian ini adalah seluruh siswa kelas VIII MTs Ulumul Qur'an Langsa yang terdiri dari 4 kelas yaitu kelas VIII-1, VIII-2, VIII-3, dan VIII-4 dengan jumlah keseluruhan siswa adalah 135 orang. Setiap kelas dalam populasi memiliki karakteristik yang sama, artinya setiap kelas tidak memiliki siswa yang pernah tinggal kelas, siswa rata-rata memiliki umur yang tidak jauh berbeda secara siginifikan, menggunakan kurikulum pendidikan yang sama.

Teknik pengambilan sampel dalam penelitian ini adalah teknik sampel acak kelompok (cluster random sampling) yakni dari 4 kelas dipilih 2 kelas sebagai sampel yang dikenakan perlakuan melalui pemilihan secara acak.

Penelitian ini menggunakan metode eksperimen dengan rancangan quasi eksperimen disain faktorial $2 \times 2$. Melalui disain ini dibandingkan pengaruh strategi pembelajaran kooperatif TGT dan strategi pembelajaran kooperatif pendekatan strukutral terhadap hasil belajar IPS ditinjau dari siswa. Strategi pembelajaran kooperatif TGT dan pendekatan strukutral diperlakukan kepada kelompok eksperimen siswa dengan kemampuan verbal yang berbeda. Strategi pembelajaran kooperatif TGT dan pendekatan strukutral sebagai variabel bebas, Perbedaan kemampuan verbal sebagai variabel moderator dan perolehan hasil belajar dalam mata pelajaran IPS sebagai variabel terikat. Variabel-variabel tersebut selanjutnya 
dimasukkan di dalam disain penelitian sebagaimana terlihat pada Tabel 1.

Tabel 1. Rancangan Eksperimen Desain Faktorial 2 x 2

\begin{tabular}{|c|c|c|}
\hline \multirow{2}{*}{ Kemampuan Verbal $(\mathbf{B})$} & \multicolumn{2}{|c|}{ Strategi Pembelajaran $(\mathbf{A})$} \\
\cline { 2 - 3 } & Kooperatif TGT $\left(\mathbf{A}_{1}\right)$ & Pendekatan Stuktural $\left(\mathbf{A}_{2}\right)$ \\
\hline Tinggi $\left(\mathbf{B}_{1}\right)$ & $\mathbf{A}_{1} \mathbf{B}_{1}$ & $\mathbf{A}_{2} \mathbf{B}_{1}$ \\
\hline Rendah $\left(\mathbf{B}_{2}\right)$ & $\mathbf{A}_{1} \mathbf{B}_{2}$ & $\mathbf{A}_{2} \mathbf{B}_{2}$ \\
\hline
\end{tabular}

Keterangan:

$A_{1} B_{1}$ : Hasil belajar siswa yang diajar dengan strategi kooperatif TGT pada siswa dengan kemampuan verbal tinggi

$A_{1} B_{2}$ : Hasil belajar siswa yang diajar dengan strategi kooperatif TGT pada siswa dengan kemampuan verbal rendah

$\mathrm{A}_{2} \quad \mathrm{~B}_{1}$ : Hasil belajar siswa yang diajar dengan strategi pendekatan struktural pada siswa dengan kemampuan verbal tinggi

$\mathrm{A}_{2} \mathrm{~B}_{2}$ : Hasil belajar siswa yang diajar dengan strategi pendekatan struktural pada siswa dengan kemampuan verbal rendah

Teknik analisis data yang digunakan adalah teknik statistik deskriptif dan inferensial. Teknik statistik deskriptif digunakan untuk mendeskripsikan data, antara lain: nilai rata-rata (mean), median, modus, varians dan simpangan baku. Teknik statistik inferensial digunakan untuk menguji hipotesis penelitian, dimana teknik Inferensial yang akan digunakan adalah teknik Analisis Varians dua jalur (disain faktorial $2 \times 2$ ) dengan taraf signifikan 0,05. Sudjana (2002) menjelaskan sebelum Anava dua jalur dilakukan, terlebih dahulu ditentukan persyaratan analisis yakni persyaratan normalitas menggunakan Uji Liliefors, sedangkan untuk uji persyaratan homogenitas menggunakan Uji Fisher dan Uji Bartlett. Setelah melakukan pengujian persyaratan analisis, selanjutnya dilakukan pengujian Anava 2 jalur, selanjutnya dilakukan uji lanjut dengan menggunakan uji Scheffe karena $\mathrm{N}$ pada setiap kelompok sel berbeda.

Untuk keperluan pengujian hipotesis, dirumuskan hipotesis statistik sebagai berikut:

Ho $: \mu \mathrm{SP}_{\text {Kooperatif TGT }}=\mu \mathrm{SP}_{\text {pendekatan struktural }}$

$$
\text { Ha }: \mu \mathrm{SP}_{\text {Kooperatif TGT }}>\mu \mathrm{SP}_{\text {Pendekatan }}
$$

struktural

Ho $: \mu \mathrm{KV}_{\mathrm{T}}=\mu \mathrm{KV}_{\mathrm{R}}$ $\mathrm{Ha}: \mu \mathrm{KV}_{\mathrm{R}}>\mu \mathrm{KV}_{\mathrm{R}}$

Ho: $\mathrm{SP}><\mathrm{KV}=0$

$\mathrm{Ha}: \mathrm{SP}><\mathrm{KV} \neq 0$

\section{HASIL DAN PEMBAHASAN \\ Hasil}

Pengujian hipotesis penelitian pertama, kedua dan ketiga dilakukan dengan menggunakan ANAVA dua jalur kemudian dilakukan uji lanjut dengan menggunakan uji Scheffe. Rangkuman hasil perhitungannya dapat dilihat pada Tabel 2 berikut ini:

Tabel 2. Rangkuman Perhitungan Anava Faktorial 2 x 2

\begin{tabular}{|l|c|c|c|c|c|}
\hline Sumber Variasi & Dk & Jk & Rjk & F-hitung & F-tabel $_{(\mathbf{1 , 5 5})}(\boldsymbol{\alpha}=\mathbf{0 , 0 5})$ \\
\hline Strategi Pembelajaran & 1 & 215,45 & 215,45 & 11,78 & 4,018 \\
Kemampuan Verbal & 1 & 490,58 & 490,58 & 26,82 & \\
Interaksi & 1 & 316,30 & 316,30 & 17,29 & \\
Galat & 55 & 1006,06 & 18,29 & & \\
Total & 58 & 2028,39 & - & & \\
\hline
\end{tabular}

Bentuk interaksi tersebut dapat disajikan pada gambar 1 berikut ini: 


\section{Rata-Rata Hasil Belajar}

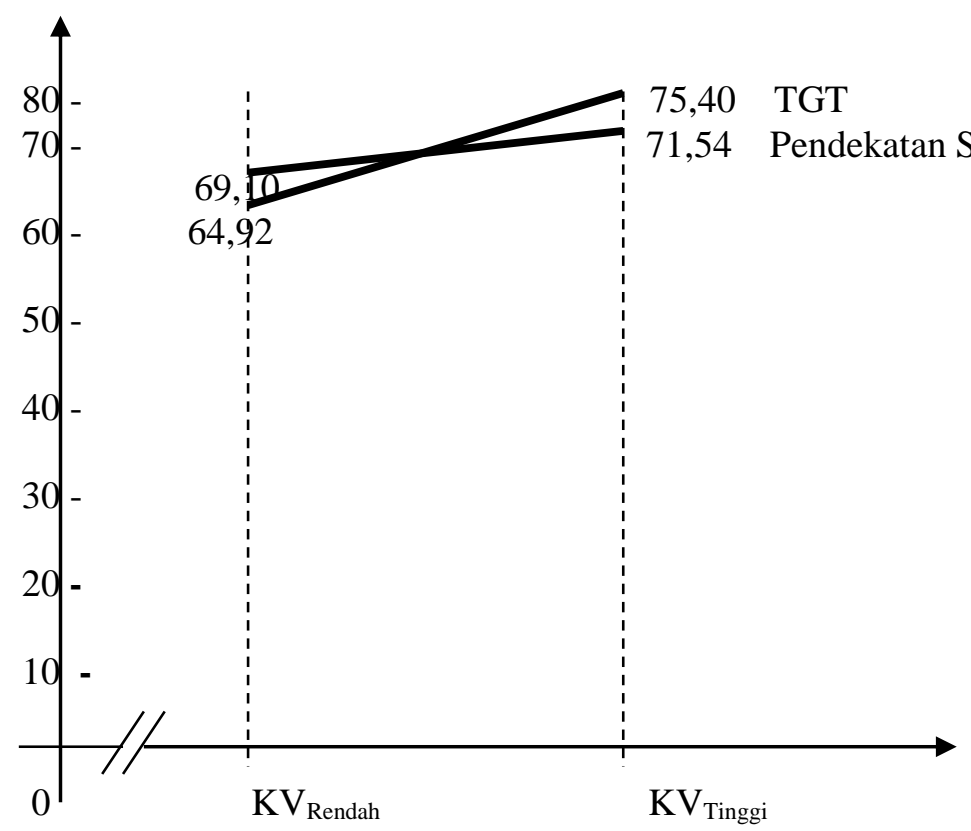

\section{Gambar 4.9 Interaksi Strategi Pembelajaran Dan Kemampuan Verbal}

Dengan terujinya secara signifikan interaksi antara strategi pembelajaran dan kemampuan verbal terhadap hasil belajar IPS, maka dilakukan uji lanjut. Sehubungan dengan jumlah sampel (n) pada setiap kelompok tidak sama, maka dilakukan uji lanjut dengan menggunakan uji Scheffe. Hasil perhitungan uji lanjut untuk setiap kelompok yang dibandingkan disajikan pada Tabel 3 berikut ini:

Tabel 3. Rangkuman Uji Scheffe

\begin{tabular}{|c|c|c|c|c|}
\hline \multicolumn{2}{|l|}{ Hipotesis Statistik } & $\mathrm{F}_{\text {-hitung }}$ & $\mathrm{F}_{\text {-tabel }(3,76)}(\alpha=0,05)$ & Keterangan \\
\hline $\mathrm{H}_{\mathrm{O}}: \mu 11=\mu 12$ & $\mathrm{Ha}_{: \mu 11>\mu 12}$ & 1,40 & 2,78 & Tidak Signifikan \\
\hline $\mathrm{H}_{\mathrm{O}: \mu 11=\mu 21}$ & $\mathrm{Ha}_{: \mu 11>\mu 21}$ & 4,42 & 2,78 & Signifikan \\
\hline $\mathrm{H}_{\mathrm{O}: \mu 11=\mu 22}$ & $\mathrm{Ha}_{: \mu 11>\mu 22}$ & 3,13 & 2,78 & Signifikan \\
\hline $\mathrm{H}_{\mathrm{O}: \mu 12=\mu 21}$ & $\mathrm{Ha}_{: \mu 12>\mu 21}$ & 3,27 & 2,78 & Signifikan \\
\hline $\mathrm{H}_{\mathrm{O}: \mu 12=\mu 22}$ & $\mathrm{Ha}_{: \mu 12>\mu 22}$ & 0,92 & 2,78 & Tidak Signifikan \\
\hline $\mathrm{H}_{\mathrm{O}: \mu 21=\mu 22}$ & $\mathrm{Ha}_{: \mu 21>\mu 22}$ & 1,91 & 2,78 & Tidak Signifikan \\
\hline
\end{tabular}

Berdasarkan hasil uji lanjut dengan uji Scheffe di atas maka dapat disimpulkan bahwa dari enam kombina pengujian maka terdapat tiga pengujian uji lanjut yang menunjukkan hasil yang signifikan dan tiga pengujian uji lanjut yang menunjukkan hasil yang tidak signifikan.

\section{Pembahasan}

Hasil pengujian hipotesis pertama menunjukkan hasil belajar IPS siswa yang diajar dengan strategi pembelajaran kooperatif TGT lebih tinggi daripada hasil belajar IPS siswa yang diajar dengan strategi pembelajaran kooperatif pendekatan struktural, dengan rata- rata hasil belajar IPS siswa yang diajar dengan strategi pembelajaran kooperatif TGT lebih tinggi daripada rata-rata hasil belajar IPS siswa yang diajar dengan strategi pembelajaran kooperatif pendekatan struktural .

Hal ini menunjukkan bahwa strategi pembelajaran Kooperatif TGT terbukti efektif dapat meningkatkan hasil belajar IPS siswa. Hasil temuan ini menunjukkan bahwa untuk mengajarkan materi ajar IPS lebih tepat menggunakan strategi pembelajaran kooperatif TGT daripada dengan strategi pembelajaran kooperatif pendekatan struktural. Hal ini sejalan dengan ungkapan Slavin (2009) menjelaskan 
pembelajaran kooperatif TGT adalah suatu tipe pembelajaran kooperatif yang menuntut siswa bekerja sama dalam satu kelompok yang terdiri dari 4-5 orang untuk saling membantu, saling memberi arahan dan bimbingan di dalam memahami materi yang disampaikan oleh guru untuk bekal dalam turnamen. Hal yang sama dipertegas Trianto (2009) bahwa pembelajaran TGT dapat digunakan dalam berbagai macam mata pelajaran dan dari jenjang pendidikan dasar sampai perguruan tinggi.

Strategi pembelajaran kooperatif TGT dapat mendorong siswa untuk aktif belajar karena siswa dapat mencari informasi-informasi yang beragam dan beraneka sumber. Di samping itu strategi pembelajaran kooperatif TGT bertujuan menumbuhkan partisipasi siswa dalam memecahkan isu atau masalah yang diajukan tenaga pengajar dalam pembelajaran, menumbuhkan diskusi di antara siswa dalam mencari penyebab dan solusi terhadap isu atau masalah tersebut. Oleh karena itu peran tenaga pengajar dalam pembelajaran kooperatif TGT sebagai fasilitator yang mengarahkan siswa untuk mengkonstruk sendiri pengetahuannya.

Temuan penelitian ini mendukung temuan penelitian Panjaitan (2010) yang menemukan peningkatan motivasi belajar siswa melalui penerapan TGT pada siklus I terdapat 26 siswa yang termotivasi belajar tinggi memperoleh ketuntasan belajar dan pada siklus kedua meningkat menjadi 34 siswa memperoleh ketuntasan belajar. Demikian juga temuan penelitian Rasyid (2004) yaitu hasil belajar Fisika siswa yang diajar dengan strategi pembelajaran kooperatif lebih tinggi dibandingkan hasil belajar Fisika siswa yang diajar dengan strategi pembelajaran ekspositori.

Jika diperhatikan lebih lanjut bahwa pada pembelajaran strategi pembelajaran kooperatif TGT rata-rata hasil belajar IPS siswa dengan kemampuan verbal tinggi lebih tinggi daripada hasil belajar IPS siswa dengan kemampuan verbal rendah. Sedangkan pada strategi pembelajaran kooperatif pendekatan struktural, rata-rata hasil belajar IPS siswa dengan kemampuan verbal tinggi lebih tinggi daripada hasil belajar IPS siswa dengan kemampuan verbal rendah. Hal ini menunjukkan bahwa kemampuan verbal signifikan untuk membedakan hasil belajar IPS siswa, di mana siswa dengan kemampuan verbal tinggi lebih baik diajar dengan strategi pembelajaran kooperatif TGT, sedangkan untuk siswa dengan kemampuan verbal rendah lebih baik diajar dengan strategi kooperatif pendekatan struktural.

Berdasarkan uraian di atas maka dapatlah dimaknai bahwa strategi pembelajaran yang tepat digunakan untuk mengajarkan IPS khususnya pada materi ajar perkembangan kolonialisme dan imperialisme Barat serta pengaruh yang ditimbulkannya pada siswa kelas VIII lebih tepat digunakan strategi pembelajaran TGT dibandingkan dengan menggunakan strategi pembelajatan pendekatan struktural. Hal ini dapat terjadi karena pembelajaran TGT menempatkan siswa dengan berbagai latar karakteristik seperti jenis kelamin, intelegensi, sebagaimana dijelaskan Trianto (2009) bahwa pada pembelajaran TGT, siswa ditempatkan dalam tim belajar beranggota beberapa siswa yang merupakan campuran menurut tingkat prestasi, jenis kelamin dan suku. Guru menyiapkan pelajaran kemudian siswa bekerja dalam tim kemudian diberi kuis berupa soal yang harus dikerjakan siswa. Kemudian guru memastikan siswa bekerja dalam kelompoknya dan memastikan siswa telah menguasai materi ajar.

Pengujian hipotesis kedua menunjukkan bahwa hasil belajar IPS siswa dengan kemampuan verbal tinggi lebih tinggi dari pada siswa dengan kemampuan verbal rendah. Hasil ini membuktikan bahwa kemampuan verbal dalam belajar signifikan untuk membedakan hasil belajar. Kemampuan verbal dalam penelitian ini dikategorikan atas dua kategori yaitu tinggi dan rendah. Dari hasil analisis data secara keseluruhan diperoleh ratarata hasil belajar IPS siswa dengan kemampuan verbal tinggi lebih tinggi daripada hasil belajar IPS siswa dengan kemampuan verbal rendah. Hal ini berindikasi bahwa siswa dengan kemampuan verbal tinggi secara rata-rata mempunyai hasil belajar IPS yang lebih baik dibandingkan dengan siswa dengan kemampuan verbal rendah. Dengan demikian siswa dengan kemampuan verbal tinggi lebih memahami dan menguasai materi ajar dibandingkan siswa dengan kemampuan verbal rendah.

Kemampuan verbal siswa merupakan faktor yang penting dalam pembelajaran kooperatif yang menuntut interaksi dan komunikasi di antara siswa. Oleh karenanya siswa dengan kemampuan verbal tinggi memiliki kemampuan dalam berkomunikasi, mencurahkan pendapatnya. Siswa yang memiliki kemampuan verbal berciri utama adanya kecakapan berbicara dengan jelas, teratur dan lancar serta memiliki 
perbendaharaan kata-kata yang baik dengan ciri-ciri khusus individu yang memiliki kemampuan verbal yang tinggi yaitu: (1) memiliki kosakata yang baik; (2) membaca dengan penuh pemahaman; (3) ingin tahu secara intelektual; dan (4) menunjukkan keingintahuan, sebagaimana penjelasan Thurstone dalam Azwar (2004) bahwa kemampuan verbal yaitu kemampuan untuk memahami hubungan/makna kata, kosakata, dan penguasaan komunikasi lisan. Hal senada dijelaskan Lewin, dkk., (2005) bahwa kemampuan verbal adalah kemampuan untuk menyusun pikiran dengan jelas dan mampu menggunakan kemampuan ini secara kompeten melalui kata-kata untuk mengungkapkan pikiran-pikiran ini dalam berbicara, membaca dan menulis.

Temuan penelitian ini mendukung penelitian sebelumnya yang dilakukan Penelitian Sibuea (2005) tentang Pengaruh Strategi Pembelajaran Dan Kemampuan Verbal Terhadap Hasil Belajar Bahasa Indonesia Siswa SMP Negeri 38 Medan menyimpulkan bahwa siswa yang memiliki kemampuan verbal tinggi ternyata memperoleh hasil belajar Bahasa Indonesia yang lebih tinggi dibandingkan dengan siswa yang memiliki kemampuan verbal yang rendah.

Pengujian hipotesis ketiga terdapat interaksi antara strategi pembelajaran dan kemampuan verbal dalam mempengaruhi hasil belajar IPS siswa. Apabila dilihat rata-rata hasil belajar IPS pada kelompok siswa dengan kemampuan verbal tinggi yang diajar dengan strategi pembelajaran Kooperatif TGT lebih tinggi dibandingkan dengan rata-rata hasil belajar kelompok siswa dengan kemampuan verbal tinggi yang diajar dengan strategi kooperatif pendekatan struktural. Kemudian rata-rata hasil belajar IPS pada kelompok siswa dengan kemampuan verbal rendah yang diajar dengan strategi pembelajaran kooperatif TGT lebih rendah dibandingkan dengan rata-rata hasil belajar siswa dengan kemampuan verbal rendah yang diajar dengan strategi pembelajaran kooperatif pendekatan struktural. Hal ini bermakna bahwa bagi kelompok siswa dengan kemampuan verbal tinggi lebih baik diajar dengan strategi pembelajaran kooperatif TGT sedangkan siswa dengan kemampuan verbal rendah lebih baik menggunakan strategi pembelajaran kooperatif pendekatan struktural.

Selanjutnya berdasarkan hasil pengujian uji lanjut menunjukkan dari 6 kombinasi yang terjadi maka terdapat 3 kombinasi yang signifikan dan 3 lainnya menunjukkan hasil yang tidak signifikan. Paparannya sebagai berikut: hasil belajar IPS siswa dengan kemampuan verbal tinggi yang diajar dengan strategi pembelajaran kooperatif TGT tidak berbeda signifikan dengan kemampuan verbal tinggi yang diajar dengan strategi pembelajaran kooperatif pendekatan struktural, dengan harga $\mathrm{F}$ hitung $=1,40<\mathrm{F}$ tabel $=2,78$, dengan rata-rata hasil belajar IPS siswa dengan kemampuan verbal tinggi yang diajar dengan menggunakan strategi pembelajaran kooperatif TGT lebih tinggi dari hasil belajar siswa dengan kemampuan verbal tinggi yang diajar dengan menggunakan strategi pembelajaran kooperatif pendekatan struktural.

Hasil belajar IPS siswa dengan kemampuan verbal tinggi yang diajar dengan strategi pembelajaran kooperatif TGT berbeda signifikan dengan kemampuan verbal rendah yang diajar dengan strategi pembelajaran kooperatif TGT, dengan harga $\mathrm{F}$ hitung $=4,42$ $<\mathrm{F}$ tabel $=2,78$ dengan rata-rata hasil belajar IPS siswa dengan kemampuan verbal tinggi yang diajar dengan menggunakan strategi pembelajaran kooperatif TGT lebih tinggi dari siswa dengan kemampuan verbal rendah yang diajar dengan strategi pembelajaran Kooperatif TGT.

Hasil belajar IPS siswa dengan kemampuan verbal tinggi yang diajar dengan strategi pembelajaran Kooperatif TGT berbeda signifikan dengan hasil belajar IPS siswa dengan kemampuan verbal rendah yang diajar dengan strategi pembelajaran kooperatif pendekatan struktural, dengan harga $\mathrm{F}$ hitung = $3,27<\mathrm{F}$ tabel $=2,78$, dengan Rata-rata hasil belajar IPS siswa dengan kemampuan verbal tinggi yang diajar dengan menggunakan strategi pembelajaran kooperatif TGT lebih tinggi dari siswa dengan kemampuan verbal rendah yang diajar dengan menggunakan strategi pembelajaran kooperatif pendekatan struktural.

Hasil belajar IPS siswa dengan kemampuan verbal tinggi yang diajar dengan strategi pembelajaran kooperatif pendekatan struktural berbeda signifikan dengan hasil belajar siswa dengan kemampuan verbal rendah yang diajar dengan strategi pembelajaran kooperatif TGT, dengan harga $\mathrm{F}$ hitung $=3,27<\mathrm{F}$ tabel $=2,78$, dengan rata-rata hasil belajar IPS siswa dengan kemampuan verbal tinggi yang diajar dengan menggunakan strategi pembelajaran kooperatif pendekatan struktural lebih tinggi dari siswa dengan kemampuan verbal rendah yang diajar 
dengan menggunakan strategi pembelajaran Kooperatif TGT .

Hasil belajar IPS siswa dengan kemampuan verbal tinggi yang diajar dengan strategi pembelajaran kooperatif pendekatan struktural tidak berbeda signifikan dengan hasil belajar IPS siswa dengan kemampuan verbal rendah yang diajar dengan strategi pembelajaran kooperatif pendekatan struktural, dengan harga $\mathrm{F}$ hitung $=0,95<\mathrm{F}$ tabel $=2,78$, dengan rata-rata hasil belajar IPS siswa dengan kemampuan verbal tinggi yang diajar dengan menggunakan strategi pembelajaran kooperatif pendekatan struktural lebih tinggi dari siswa dengan kemampuan verbal rendah yang diajar dengan strategi pembelajaran kooperatif pendekatan struktural.

Hasil belajar IPS siswa dengan kemampuan verbal rendah yang diajar dengan strategi pembelajaran Kooperatif TGT tidak berbeda signifikan dengan hasil belajar siswa dengan kemampuan verbal rendah yang diajar dengan strategi pembelajaran kooperatif pendekatan struktural, dengan harga $\mathrm{F}$ hitung = $1,91<\mathrm{F}$ tabel $=2,78$, dengan rata-rata hasil belajar IPS siswa dengan kemampuan verbal rendah yang diajar dengan menggunakan strategi pembelajaran kooperatif TGT lebih rendah dari siswa dengan kemampuan verbal rendah yang diajar dengan menggunakan strategi pembelajaran kooperatif pendekatan struktural.

Berdasarkan uraian di atas maka dapatlah dimaknai bahwa pada siswa dengan karakteristik kemampuan verbal yang berbeda maka guru melakukan perlakuan yang berbeda dalam menerapkan strategi pembelajaran. Untuk siswa dengan karakteristik kemampuan verbal tinggi lebih tepat diajar dengan strategi pembelajaran koperatif TGT, sedangkan siswa dengan karakteristik kemampuan verbal rendah lebih tepat diajar dengan strategi pembelajaran pendekatan struktural.

\section{PENUTUP}

\section{Simpulan}

Pertama, rata-rata hasil belajar IPS siswa yang diajar dengan strategi pembelajaran kooperatif TGT lebih tinggi dibandingkan dengan rata-rata hasil belajar siswa yang diajar dengan strategi pembelajaran kooperatif pendekatan struktural. Dengan demikian strategi pembelajaran kooperatif TGT lebih efektif diterapkan dalam pembelajaran IPS khususnya pada materi ajar proses kebangkitan nasional daripada strategi pembelajaran pendekatan struktural.

Kedua, rata-rata hasil belajar IPS siswa dengan kecenderungan tingkat kemampuan verbal tinggi secara keseluruhan baik yang diajar dengan strategi pembelajaran kooperatif TGT dan strategi pembelajaran kooperatif pendekatan struktural lebih tinggi dibandingkan dengan rata-rata hasil belajar IPS siswa dengan kecenderungan tingkat kemampuan verbal rendah.

Ketiga, perbedaan pengaruh strategi pembelajaran dan kemampuan verbal adalah siswa dengan kemampuan verbal tinggi lebih tepat diajar dengan strategi pembelajaran kooperatif TGT daripada diajar dengan strategi pembelajaran kooperatif pendekatan struktural, sedangkan siswa dengan kemampuan verbal rendah lebih baik diajar dengan strategi pembelajaran kooperatif pendekatan struktural daripada diajar dengan strategi pembelajaran kooperatif TGT.

\section{Saran}

1. Kepada pihak tenaga pengajar perlu melihat karakteristik kemampuan verbal siswa di dalam menerapkan strategi pembelajaran kooperatif TGT dan kooperatif pendekatan struktural. Untuk siswa dengan kemampuan verbal tinggi lebih tepat diajar dengan strategi pembelajaran kooperatif TGT sedangkan bagi siswa dengan kemampuan verbal rendah maka strategi pembelajaran yang lebih tepat diterapkan adalah strategi pembelajaran kooperatif pendekatan struktural.

2. Kepada pihak pengelola MTs Ulumul Qur'an Langsa agar memotivasi guru-guru dalam kegiatan pembelajaran untuk menerapkan strategi pembelajaran kooperatif TGT karena melalui penelitian ini terbukti bahwa pembelajaran kooperatif TGT dapat meningkatkan hasil belajar.

3. Kepada peneliti lain yang ingin meneliti lebih lanjut tentang strategi pembelajaran kooperatif TGT hendaknya memperhatikan variabel-variabel lainnya khususnya yang berkaitan dengan karakteristik siswa sepertyi gaya belajar, kemampuan awal, gaya kognitif dan sebagainya sehingga diperoleh pengetahuan yang lebih komprehensif lagi.

\section{DAFTAR PUSTAKA}

Aiken, L. R. 1997. Psychological Testing And Assessment Ninth Edition. Pepperdine University: Allyn and Bacon 
Arend, I.R. 2008. Learning To Teaching. Buku Dua. Penerjemah Helly Prajitno Soetjipto dan Sri Mulyantini Soetjipto, Yogyakarta: Pustaka Pelajar

Azwar, S. 2004. Psikologi Intelegensi. Yogyakarta: Pustaka Pelajar

Badiran, M. Sibuea, A.M dan Yusri. 2008. "Pengembangan Model Pembelajaran Seni Rupa Sebagai Upaya Meningkatkan Mutu Belajar Mengajar Seni Rupa. Medan”. Jurnal Teknologi Pendidikan Pascasarjana Unimed.

Bahari, Y. (2005). "Pengaruh Strategi Pembelajaran Kooperatif Dan Kreativitas Siswa Terhadap Hasil Belajar Matematika Siswa MIN Medan". Tesis. Medan: Unimed

Dick, W. Carey, L dan Carey, J. 2005. The Systematic Design of Instruction. Fouth Edition. New York: Harper Collin College Publisher

Djamarah, S.B. \& Zain, A. 2002. Strategi Belajar Mengajar. Jakarta: Rineka Cipta

Gagne, R.M. 1977. The Conditioning of Learning. New York: Hall, Rinehort and Winston.

Gulo, W. 2008. Strategi Belajar Mengajar. Jakarta: Grasindo

Hergenhahn, B.R dan Olson, M.H. 2008. Theories of Learning (Teori Belajar). Alih Bahasa: Tri Wibowo BS. Jakarta: Kencana Prenada Media Group

Lewin, M., Adam K., Kenneth L. dan Caroline S. (2005). How To Multypy Your Child's Intelligence Cara Mengembangkan Berbagai Komponen Kecerdasan Petunjuk Praktis Bagi Guru Masyarakat Umum, dan Orang Tua. Alih Bahasa: Marianto Samosir. Jakarta: Indeks

Lie, A. 2004. Cooperative Learning (Mempraktikkan Cooperative Learning di Ruang-Ruang Kelas). Jakarta: Grasindo

Merril, M. D., dan Twitchell. 1994. Instructional Design Theory. New Jersey: Englewood Cliffs.

Merill, M.D. 1981. A Lesson Based on the Component Display Theory. New Jersey: Lawrence Erlbaum Ass.

Mudhoffir, 1993. Teknologi Instruksional. Bandung: Rosdakarya

Muijs, D. dan Reynold D. (2008). Effective Teaching Teori dan Aplikasi. Penerjemah: Helly Prajitno Soetjipto dan Sri Mulyanti Soetjipto. Yogyakarta: Pustaka Pelajar
Mulyati. 2005. Psikologi Belajar. Yogyakarta: Andi

Nurhadi. E. 2003. Contekstual Teaching and Learning. Jakarta: Departemen Pendidikan Nasional

Payong, M.R.. 2005. "Pengaruh Strategi Pembelajaran Kolaboratif dan Kompetitif dan Komunikasi Interpersonal Terhadap Hasil Belajar PPKn Siswa SMA 03 Jakarta". Jurnal TP UNJ

Riyanto, Y. 2010. Paradigma Baru Pembelajaran. Jakarta: Kencana Prenada Media Group

Romizowski, AZ. 1981. Designing Instructional System. New York: Nichol Publishing Company

Rozi, F. 2010. "Penerapan Model Pembelajaran Kooperatif Tipe Jigsaw Melalui Pembelajaran Aktif, Kreatif, Efektif dan Menyenangkan Untuk Meningkatkan Hasil Belajar IPA dan Kecakapan Sosial Siswa Kelas IV B SD Al-Azhar Medan". Tesis: Unimed

Sanjaya, W. 2007. Strategi Pembelajaran Berorientasi Standar Proses Pendidikan. Jakarta: Kencana Prenada Media Group

Sibuea, A.M. dan Amin, M. 2005. "Aspek Psikologi dan Hasil Belajar Siswa SLTP Yang Menggunakan Model Pembelajaran Akselerasi di Kota Medan. Medan". Jurnal Penelitian Bidang Pendidikan Volume II No. 2. Lembaga Penelitian Unimed.

Slameto. 2005. Belajar dan Faktor- Faktor Yang Mempengaruhinya. Jakarta : Rineka Cipta.

Slavin, R.E 2009. Cooperative Learning, Teori, Riset dan Praktek. Bandung: Nusa Media

Suparman, A. 2001. Desain Instrusional, Jakarta: Universitas Terbuka

Suryabrata, S. 2002. Psikologi Pendidikan. Jakarta: Raja Grafindo Persada

Syah, M. 2004. Psikologi Belajar. Jakarta: Raja Grafindo Persada

Taniredja, T., Faridli, M., dan Harmianto, S. 2011. Model-Model Pembelajaran Inovatif. Bandung: Alfabeta

Trianto. 2009. Mendesain Model Pembelajaran Inovatif Progesif. Jakarta: Kencana Prenada Media Group

Yamin, M. 2011. Paradigma Baru Pembelajaran. Jakarta: Gaung Persada

Yuni, N. (2003). "Perbedaan Hasil Belajar Matematika Siswa Dengan Menggunakan Metode Pembelajaran Kooperatif Dan Metode Pembelajaran Konvensional Pada 
Jurnal Teknologi Pendidikan, Vol. 8 No. 2 Oktober 2015, p-ISSN; 1979-6692, e-ISSN: 2407-7437

Pokok Bahasan Matriks Di Kelas I SMP”. Tesis: Pascasarjana Unimed

Woolfolk. A.E. 2009. Educational Psychology Active Learning Edition. Bagian Pertama.
Penerjemah: Helly Prajitno Soetjipto dan Sri Mulyanti Soetjipto. Yogyakarta: Pustaka Pelajar 